Bryn Mawr College

Scholarship, Research, and Creative Work at Bryn Mawr

College

1987

\title{
Crustal Deformation and Regional Metamorphism Across a Terrane Boundary, Coast Plutonic Complex, British Columbia
}

Maria Luisa Crawford

Bryn Mawr College, mcrawfor@brynmawr.edu

L. S. Hollister

G. J. Woodsworth

Let us know how access to this document benefits you.

Follow this and additional works at: http://repository.brynmawr.edu/geo_pubs

Part of the Geology Commons

\section{Custom Citation}

Crawford, M. L., L. S. Hollister, and G. J. Woodsworth (1987) Crustal Deformation and Regional Metamorphism Across a Terrane Boundary, Coast Plutonic Complex, British Columbia, Tectonics, 6, no. 3, 343-361.

This paper is posted at Scholarship, Research, and Creative Work at Bryn Mawr College. http://repository.brynmawr.edu/geo_pubs/6

For more information, please contact repository@brynmawr.edu. 
TECTONICS, VOL. 6, NO. 3, PAGES 343-361, JUNE 1987

CRUSTAL DEFORMATION AND REGIONAL METAMORPHISM ACROSS A TERRANE BOUNDARY, COAST PLUTONIC COMPLEX, BRITISH COLUMBIA

\author{
M.L. Crawford \\ Department of Geology, Bryn Mawr College, \\ Pennsylvania
}

L.S. Hollister

Department of Geological and Geophysical Sciences, Princeton University, New Jersey

G.J. Woodsworth

Geological Survey of Canada, Vancouver

Abstract. The Coast Plutonic Complex between Prince Rupert and Terrace, British Columbia, developed in two stages between mid-Cretaceous and mid-Eocene time. The early stage ( $>100-70 \mathrm{Ma}$ ) involved crustal thickening as the amalgamated Alexander and Wrangellia terranes were emplaced against the Stikine terrane to the east. This thickening resulted from tectonic stacking of crustal slabs, lubricated by intrusion of melt generated at the base of the thickened crust. Emplacement of westward directed thrust slabs along the western margin of the orogen was accompanied by intrusion of a high pressure epidote-bearing tonalite pluton and associated sills. Thrusting resulted in inversion of the metamorphic sequence as supracrustal rocks buried early in the collision were tectonically exhumed. Pluton emplacement also accompanied eastward directed thrusting of high temperature gneisses over low-grade rocks on the eastern margin of the orogen as the tectonic welt was backthrust over Stikinia. The earliest recognized events in the core of the orogen involve pervasive ductile deformation accompanied by

Copyright 1987

by the American Geophysical Union.

Paper number $7 \mathrm{~T} 0169$.

0278-7407/87/007T-0169\$10.00 emplacement of tonalite sills between about 85 and $50 \mathrm{Ma}$. Uplift of the orogen core between 60 and $48 \mathrm{Ma}$ coincided with and was facilitated by emplacement of large volumes of tonalitic magma, accompanied by anatexis and the development of ductile shear zones. One of these shear zones, the Work Channel lineament, presently separates the core of the orogen from the schists to the west. The main orogenic cycle ended by $48 \mathrm{Ma}$ when the rocks cooled rapidly through the biotite and hornblende Ar blocking temperatures. The time and space associations of deformation, metamorphism, and plutonic intrusion imply that substantial differential movement occurred across zones which contained fluid during deformation of the Coast Plutonic Complex. In the region of westward directed thrusting and inverted metamorphism, melts generated in the tectonically thickened lower crust and fluids released during metamorphic recrystallization of supracrustal rocks, which were rapidly buried during tectonic thickening, acted to reduce the strength of the crust. In the core zone of the complex, injections of tonalite magma into the lower crust induced pervasive anatexis. The weakened core zone yielded along both low angle and steep shear zones that were further lubricated by melt as the relatively buoyant hot crust rose rapidly in response to continued compression and underthrusting. 


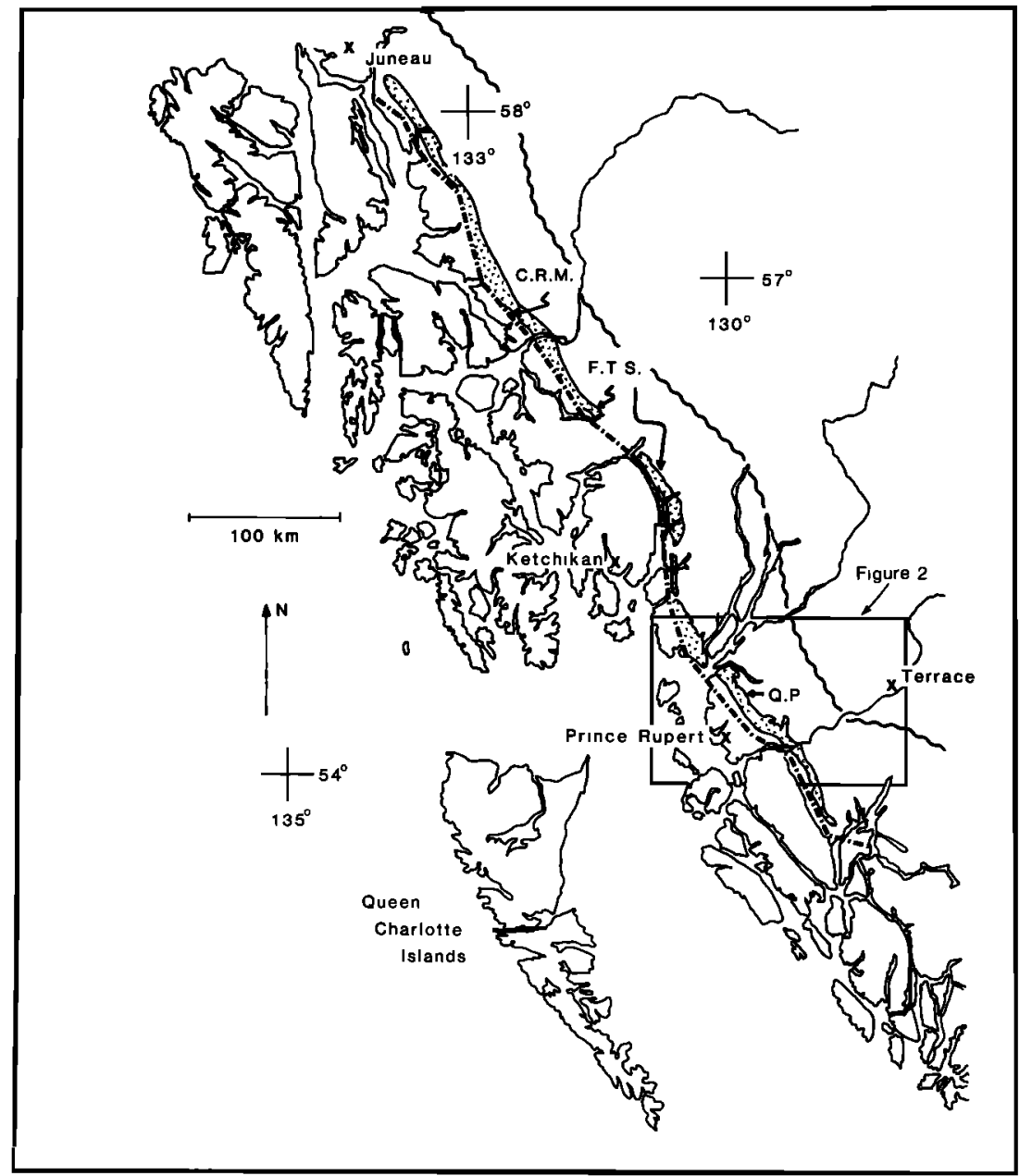

Fig. 1. Generalized map of coastal British Columbia and southeastern Alaska showing the location of the Prince Rupert-Terrace area of Figure 2. The heavy dot-dash line is the trace of the Coast Range megalineament (C.R.M.) [Brew and Ford, 1978], which becomes the Work Channel lineament in British Columbia. Just east of this lineament lies the foliated tonalite sill (F.T.S.)[Brew and Ford, 1978], including the Quottoon pluton (Q.P.) in British Columbia. The wavy line separates the low-grade metamorphic rocks of the eastern belt from the higher-grade rocks of the Central Gneiss Complex.

\section{INTRODUCTION}

The location of Phanerozoic regional metamorphic terranes suggests they form an integral component of the tectonic processes at collisional plate boundaries. The distribution of metamorphic facies in these terranes, the mechanisms for imposing metamorphic temperature and pressure conditions on the rocks, the associated intense deformation, and the source of the synmetamorphic and postmetamorphic igneous rocks have been modelled using various interpretations of processes at these plate boundaries.
Examples include crustal thickening by overthrusting and/or underthrusting [Oxburgh and Turcotte, 1974; Crawford and Mark, 1982], by buckling during collision [Dewey and Burke, 1973], and by addition of magmatic material [Wells, 1980]. In this paper we present the thermal and structural history deduced for a transect across the British Columbia-Alaska Coast Plutonic Complex between latitudes $54^{\circ}$ and $55^{\circ}$ North (Figure 1). The transect straddles two major terranes: the amalgamated Alexander and Wrangellia terranes (Insular Superterrane) on the west and the Stikine terrane to the east 


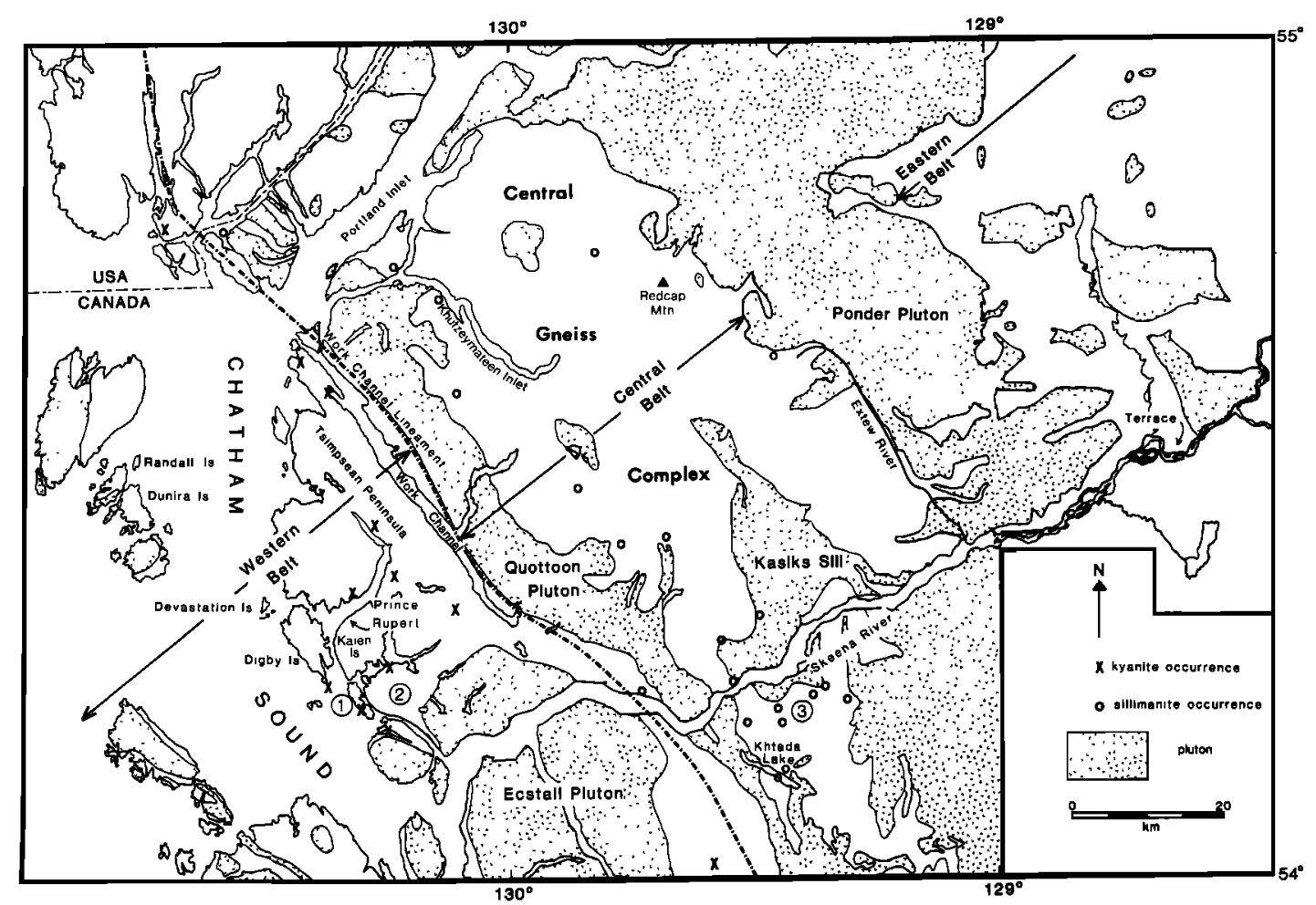

Fig. 2. Map of the Prince Rupert-Terrace area showing the distribution of the western, central, and eastern belts and of the large intrusive bodies (patterned). The Work Channel lineament (dot-dash line) separates the western and central belts; the boundary between the central and eastern belts lies within the area mapped as Ponder pluton. Kyanite and sillimanite-bearing localities are shown to emphasize the contrast in metamorphic mineral assemblages between the western and central belts. Localities 1,2 , and 3 are used for reference in the text and in Figures 3 and 8 .

[Monger et al., 1982]. Thus the history we describe and interpret documents the processes which occur in convergence and collision between continental crustal blocks. In our interpretation each of the processes listed above played a role in the development of the Coast Plutonic Complex.

Our transect, between Prince Rupert and Terrace, British Columbia, crosses the Coast Plutonic Complex midway along its length and has reasonably good access by highway, boat and helicopter. Mapping of the area (Figure 1, Figure 2) on a reconnaissance scale [Hutchison, 1982] was completed by 1967. Using Hutchison's work as a base, we have reexamined in greater detail the coastal area from Prince Rupert north to the Canada-Alaska border and the mountains on either side of the Skeena River east of Work Channel (Figure 2).

Our interpretation is based on the stratigraphy, the structural data, the constraints of thermal history inferred from the metamorphic assemblages and from the plutonic rocks, and on the age constraints using presently available geochronologic data. The data are summarized in Table 1. The orogen developed from mid-Cretaceous to middle Eocene time with minor igneous activity and local faulting continuing to the present. The early stage involved eastward directed synmetamorphic imbricate underthrusting of Insular Superterrane units along the western margin of the present belt. As the orogen developed regional scale thrusts and nappes formed accompanied by injection of magma within and adjacent to zones of ductile deformation. Supracrustal rocks were buried to depths of about $25-30 \mathrm{~km}$ and were subsequently uplifted along thrust faults on both margins of the orogen. In the orogen core, emplacement of syntectonic tonalite bodies and sills raised the 


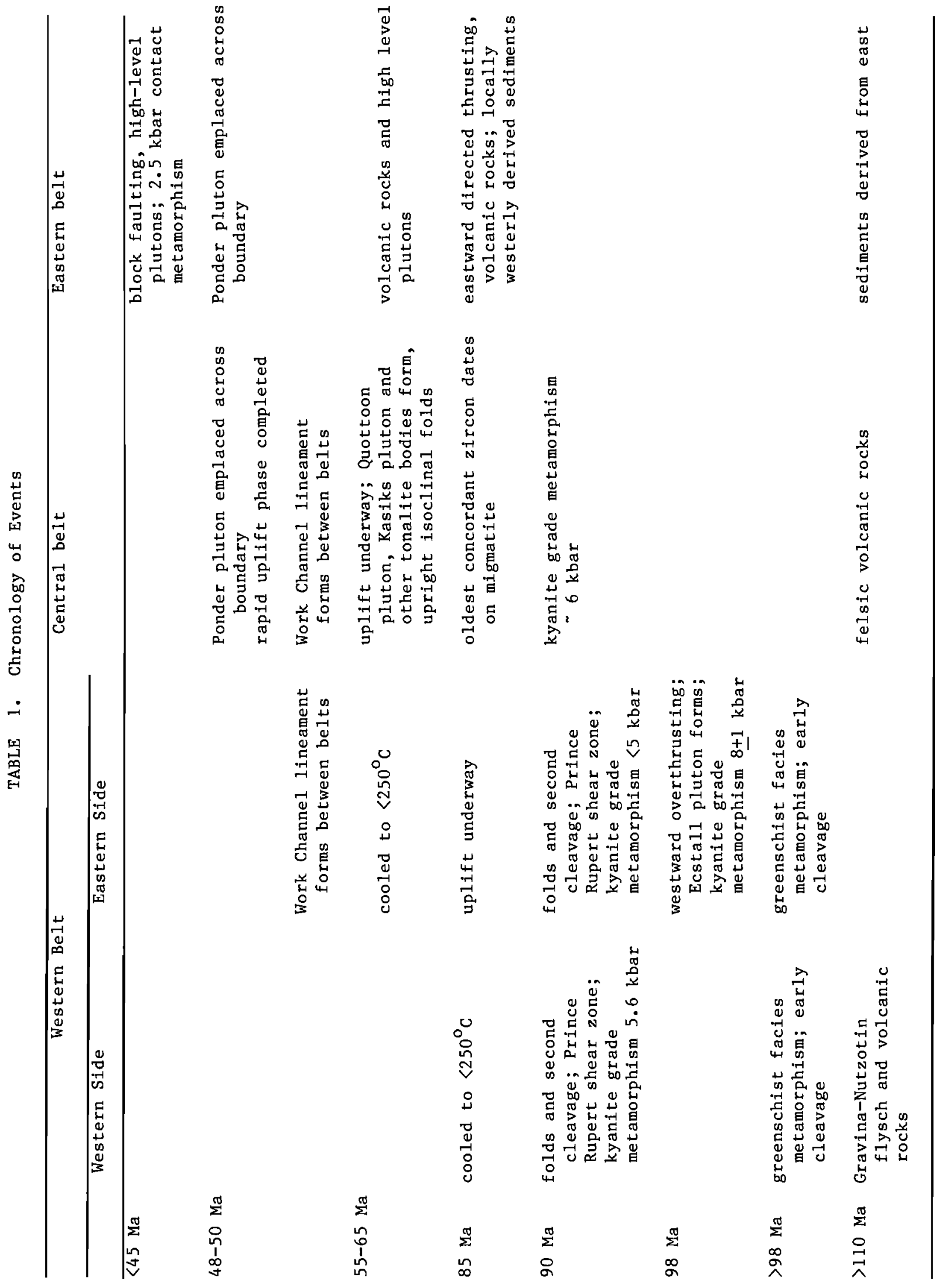


temperature of those core rocks and produced additional crustal thickening. Total crustal thickening may have exceeded $60 \mathrm{~km}$. Rapid uplift $(\sim 1 \mathrm{~mm} / \mathrm{yr})$ of crustal blocks in the orogen core along steep regional shear zones raised the tectonically buried supracrustal rocks and associated plutons to shallow crustal levels. The presence along shear zones of anatectic melt as well as injected tonalite probably assisted and accelerated the major crustal deformation.

\section{REGIONAL GEOLOGY--OVERVIEW}

The area of the traverse is subdivided into three distinct belts separated by tectonic breaks which have been traced for much of the length of the Coast Mountains: the low- to high-grade schists and gneisses of the western metamorphic belt, the high grade gneisses and associated plutonic bodies of the Central Gneiss Complex in the central belt, and the very low grade to unmetamorphosed sedimentary and volcanic rocks of the eastern belt (Figure 2).

Low-grade metamorphic rocks of the western metamorphic belt include fossiliferous Mississippian, Pennsylvanian, and Upper Triassic strata and Lower Jurassic rhyolite [Woodsworth et al., 1983a; Woodsworth and Orchard, 1985] which can be traced from Randall and Dunira Islands to Devastation and Digby Islands just west of Prince Rupert (Figure 2). According to Woodsworth and Orchard [1985] these rocks may correlate with units mapped by Berg et al. [1978] as part of the Alexander Terrane in southeastern Alaska. They are overlain by carbonaceous argillite and conglomerate that resemble rocks of the Gravina-Nutzotin belt exposed in the Ketchikan quadrangle [Berg et al., 1972]. In the eastern belt, $130 \mathrm{~km}$ southeast of this traverse in the Whitesail Lake map area, east of the highgrade crystalline rocks, Lower Jurassic rocks characteristic of the Stikine terrane can be traced westward into medium- to high-grade schists flanking the eastern edge of the Central Gneiss Complex of the central belt [Woodsworth, 1979; van der Heyden, 1982]. Ages for the protolith of the high grade metasedimentary rocks in the western belt east of Prince Rupert and in the central belt are unknown. However, fossils recently found in the Central Gneiss Complex west of Terrace [Hill, 1985] may correlate with upper Paleozoic fauna from the Stikine terrane. Several concordant $\mathrm{U} / \mathrm{Pb}$ dates have been obtained from migmatite of the Central Gneiss Complex; they range from 65 to $85 \mathrm{Ma}$ [Woodsworth et a1., 1983b]. An older nearly concordant $\mathrm{U} / \mathrm{Pb}$ date of $139 \mathrm{Ma}$ has been obtained on a nonmigmatitic leucogneiss [Hill, 1984]. This is the oldest date from the Central Gneiss Complex of British Columbia and provides a minimum age for at least part of the premetamorphic protolith of the central belt.

The western and central belts are separated by the Work Channel lineament zone (Figure 2) which contains vertically foliated mylonite and augen gneiss with near-vertical lineations. The transition between the central and eastern belts is largely obliterated by Ponder Pluton and other syntectonic to posttectonic plutons. However, at one place in our section, in a highway cut along the Skeena River, the contact zone between the central belt gneisses and the greenschist facies rocks to the east lies along greenschist facies mylonitic gneiss dipping gently northwest and along northwest trending, steep brittle faults. Westerly dipping mylonites were also recognized at this contact $130 \mathrm{~km}$ to the southeast by van der Heyden [1982, 1985].

Each belt has a different and distinct history, the details of which are presented below.

\section{WESTERN BELT}

The western metamorphic belt consists of at least three tectonically juxtaposed packets of interlayered well-foliated metasedimentary and metavolcanic rocks cut by thrust faults and shear zones. In general, limbs of isoclinal folds, metamorphic foliation, and thrust faults dip at low to moderate angles to the east or southeast [Crawford and Hollister, 1982]. The vergence on all structures is to the west or northwest, so the schists along the eastern side of the belt occupy the structurally highest position. Metamorphic grade increases from west to east from chlorite through garnet, chloritoid, staurolite, and kyanite + migmatite zones. The high-grade part of this metamorphic sequence is inverted, whereby the schists and gneisses that lie at the highest structural levels along the eastern boundary of the belt (e.g., locality 2, Figure 2) contain the highest pressure mineral assemblages $(8+1 \mathrm{~Kb})$, pressures equivalent to burial at depths of about $30 \mathrm{~km}$ (Figure 3 ). 


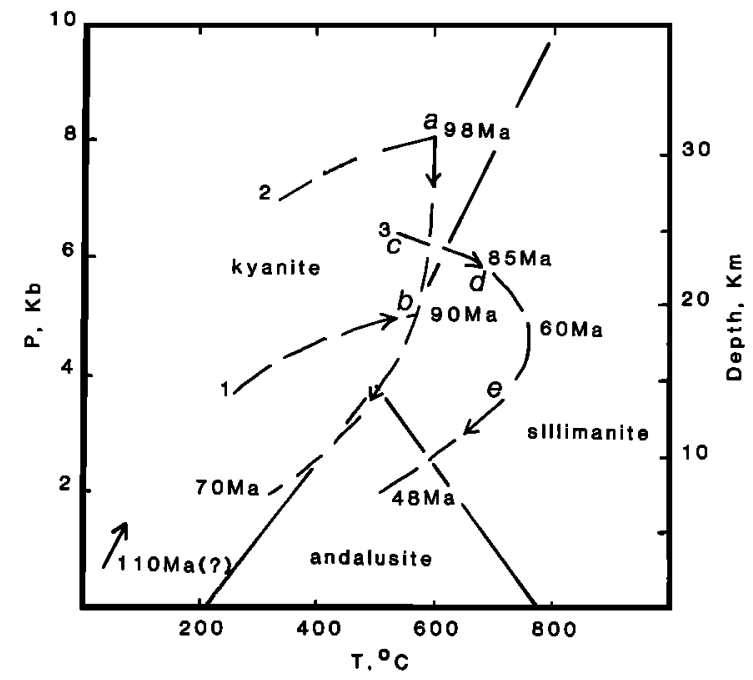

Fig. 3. Pressure-temperature diagram summarizing the history of the rocks at localities 1,2 , and 3 of Figure 2. Paths 1 and 2 are for rocks in the western belt; path 3 is for rocks in the central belt. Points a, b, c, d, and e are referred to in the text. The stability fields of kyanite, sillimanite, and andalusite are shown for reference. All three paths start at the surface $\left(P=0 \mathrm{kbar}, \mathrm{T}=25^{\circ} \mathrm{C}\right)$, possibly at $110 \mathrm{Ma}$, and return to the surface. The ages of specific points on the P-T trajectories are based on isotopic data discussed in the text.

Only the rocks in the structurally lowest packet, exposed on the islands west of Chatham Sound, along the western shore of Tsimpsean Peninsula and on Digby Island (Figure 2, Figure 4), preserve sufficient information to permit correlation with adjacent areas. These are the units identified above as belonging to the Alexander terrane and the Gravina-Nutzotin belt. Primary sedimentary structures in fine-grained dark siltstones and the easterly younging stratigraphy described by Woodsworth and Orchard [1985] indicate that the rocks are right side up. Tonalite and granodiorite plutons that intrude these greenschist facies schists postdate the development of a regional east dipping foliation [Hutchison, 1982]. Ninety-six- and 84-Ma K/Ar dates on biotite from these plutons [Hutchison, 1982] give a minimum age for the deformation and low-grade metamorphism. The maximum age is given by a $186 \mathrm{Ma} \mathrm{U} / \mathrm{Pb}$ date on zircons from metamorphosed rhyolite [Woodsworth and Orchard, 1985].
The top of the lowest packet is the Prince Rupert shear zone that lies along the western side of Kaien Island and in the city of Prince Rupert (Figures 4 and 5a). As this zone is approached from the west, an increasingly intense second deformation is imposed on the low-grade schists. The field evidence suggests that this second deformation in the schists of the lowest packet is associated with formation of the shear zone. The first manifestation of this second deformation is a spaced cleavage that dips $30^{\circ}$ to $50^{\circ} \mathrm{E}$ or SE and cuts both limbs of the early isoclinal folds and the associated first foliation (marked by muscovite and chlorite parallel to compositional layering). This is shown diagrammatically at the western end of section $A-A^{-}$(Figure 5a). Plagioclase-phyric andesitic(?) dikes up to several meters thick lie parallel or at a low angle to this second cleavage. The margins of the dikes are foliated, although the centers of the thicker ones are generally massive. The fine-grained matrix of the dikes has been entirely altered and recrystallized to chlorite, albite, and carbonate but the plagioclase phenocrysts appear fresh. The orientation of the dikes, their metamorphism, and their deformation all suggest they were intruded during the deformation that formed the second cleavage. Close to the Prince Rupert shear zone, the spaced cleavage becomes a penetrative foliation associated with recumbent tight to isoclinal folds a few meters in amplitude. Quartz veins oriented parallel and perpendicular to the foliation increase in abundance. The schists as well as greenstone dikes, similar to the plagioclasephyric dikes to the west, are pervasively deformed, obliterating earlier structures. Within the shear zone itself the foliation is disrupted into a complex of tectonic boudins each a few to tens of meters long. A distinct decrease in grain size is attributed to recrystallization during intense flattening and shearing.

Metamorphic grade increases rapidly across Digby Island. Mineral textures suggest that biotite, garnet, staurolite, and kyanite nucleated and grew during the second deformation (Table 1). In fissile units in the lower-grade schists on the west coast of Digby Island, biotite occurs in small wrinkles of the early foliation. In other units, biotite flakes are oriented parallel to the second spaced cleavage. In higher-grade schists close 


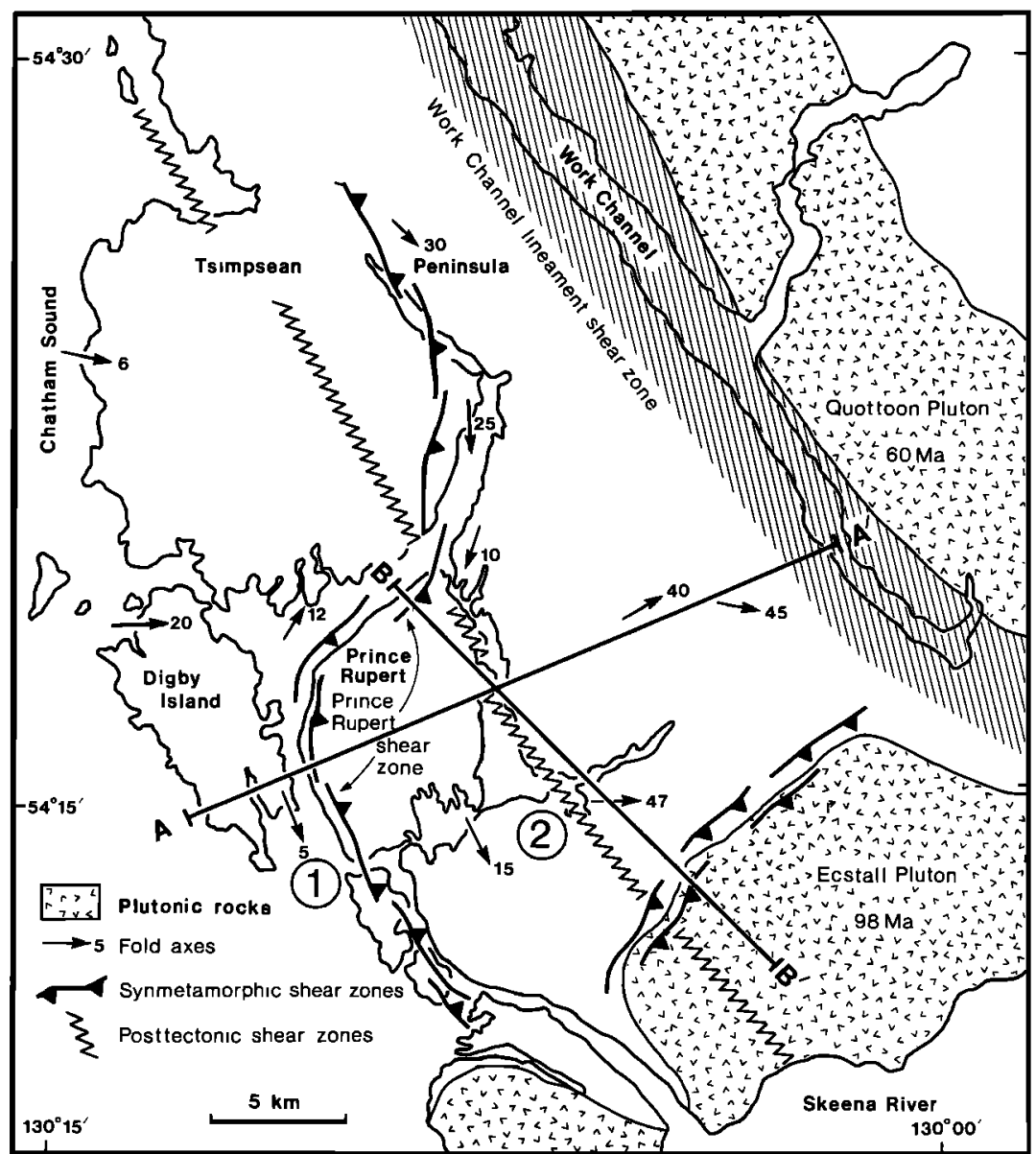

Fig. 4. Map of the Prince Rupert area, western belt, showing the location of cross sections $\mathrm{AA}^{-}$and $\mathrm{BB}^{-}$(Figure 5). The zones of most intense early shearing are labelled synmetamorphic shear zones. Late (young) shears are vertical zones of brittle deformation.

to the shear zone, garnet and staurolite show helicitic textures that apparently developed due to slip along the follation as those minerals grew. Porphyroblasts, including kyanite, are stretched and fractured in small scale analogues of the boudinage of the rock layers. This metamorphism has been dated at $90+1$ Ma by ${ }_{\mathrm{Ar}} /{ }^{40} \mathrm{Ar}$ dates on hornblende [Sutter and Crawford, 1985]. The garnet-biotite geothermometer [Ferry and Spear, 1978] and the garnet-plagioclase-kyanite-quartz geobarometer [Ghent, 1976] suggest that kyanite crystallized in these schists (locality 1, Figure 2; Figure 3) at 5.6+.5 kbar and $560^{\circ}+20^{\circ} \mathrm{C}$. This contrasts with higher pressures and temperatures derived from overlying units east of the shear zone (locality 2, Figure 2; Figure 3).

Lithologic changes across the shear zone suggest that it represents the eastern boundary of the Alexander terrane. None of the units in the lower packet, described above as correlative with Alexander terrane rocks, are recognized east of (above) the shear zone. Above the shear zone the rocks are predominantly biotite-hornblende quartz schists suggesting a greywacke or similar protolith. Amphibolite units interlayered with the schists throughout the upper packet may represent mafic volcanic units. Some of the schists above the shear zone are calcareous, but thicker marble units like the upper Paleozoic and Triassic units assigned to the Alexander terrane and dark carbonaceous schists and conglomerates correlated with GravinaNutzotin flysch are not present.

Structural style and metamorphic grade 

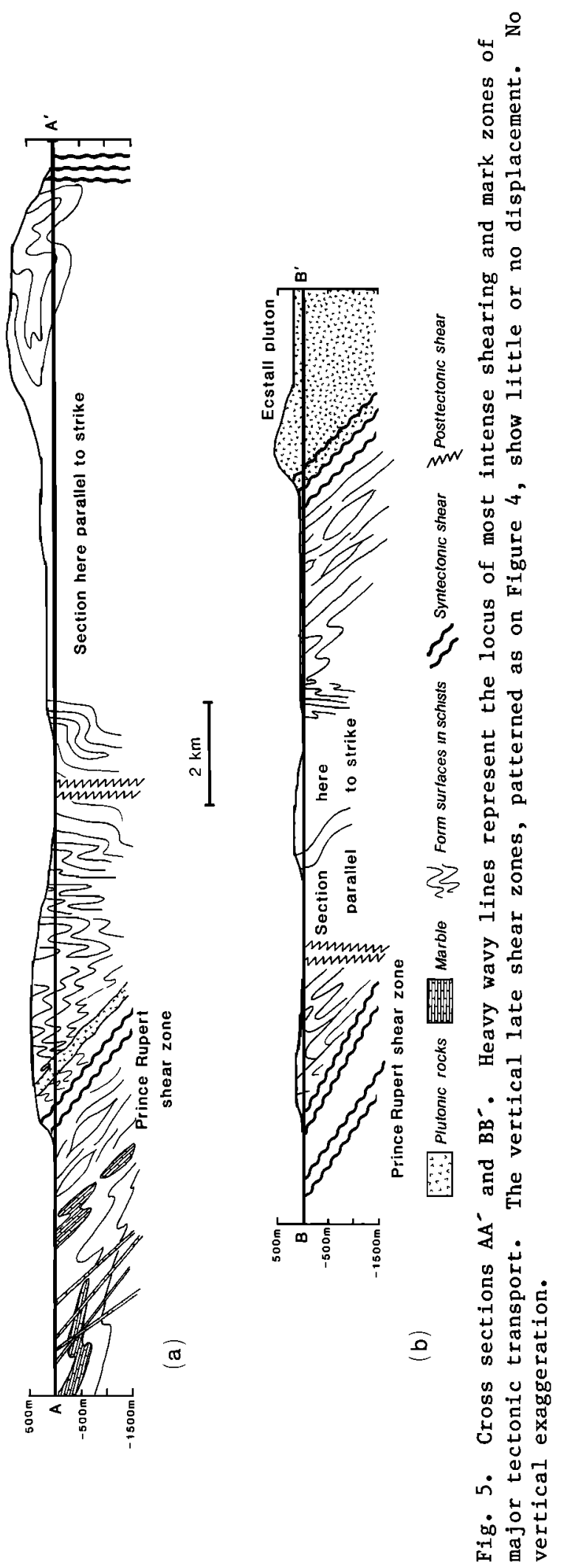

also differ in the packet of schists that lie above the shear zone (Figure $5 a$ ). Immediately above the shear zone, upright isoclinal folds on a scale of meters to tens of meters, which plunge $10^{\circ}$ to $15^{\circ}$ to the south, refold an earlier foliation. These relations and the fact that these folds die out eastward suggest that they may have formed during tectonic emplacement of this middle schist packet over the lower packet to the west. Kyanite, aligned parallel to the upright isocline fold axes and in quartz-filled boudin necks demonstrates that the upright folds formed during kyanite-grade metamorphism. Crawford et al. [1979] present evidence for high-pressure and high-temperature ( 8 kbar, $625^{\circ} \mathrm{C}$ ) mineral assemblages in these schists. This metamorphism is inferred to precede the kyanite grade metamorphism of the rocks in the underlying schist packet to the west (Table 1, Figure 3 ). Zoning patterns in the garnet and plagioclase in kyanite-staurolite schists record a history of continuing mineral growth to lower-pressure conditions ( $\sim 4 \mathrm{kbar})$. We suggest that this represents continuing mineral growth during uplift and emplacement of this schist packet over the lower packet before metamorphism ceased.

The Ecstall Pluton and its immediately surrounding country rocks represent a third and uppermost high-pressure packet of rocks. Kyanite-bearing migmatitic country rock schists and gneisses in the vicinity of the Ecstall pluton record pressures of $8+1 \mathrm{kbar}$ and temperatures above $600^{\circ} \mathrm{C}$. The Ecstall pluton contains primary magmatic epidote, suggesting crystallization at high pressure [Crawford and Hollister, 1982; Zen and Hammarstrom, 1984]. Close to the pluton a strong shear fabric is encountered. Folds are flattened and obliterated, mineral grain size decreases, the schist develops a strong planar foliation, and locally the rock contains lenticular patches that apparently result from transposition of individual layers (Figure 5b). Elsewhere in this uppermost packet, structures in the migmatitic quartzofeldspathic and hornblende gneisses have an arcuate pattern parallel to the northern contact of the Ecstall Pluton. The gneissic banding is folded into meter-sized recumbent, northwesterly verging folds with sheared-off lower limbs and gently dipping axial surfaces. These folds are interpreted to have formed during emplacement of the Ecstall pluton while the schists were at high pressures. 
The pluton contact parallels the shear foliation in the schist; the schist and the foliation dip gently east and southeast under the intrusive body. At its margin the pluton also shows a strong penetrative foliation. Toward the pluton interior this shear foliation grades into a migmatitic foliation defined by alignment of magmatic hornblende and oriented elongate mafic inclusions. This magmatic flow foliation parallels both the pluton contact and the foliation in the country rock; it becomes less distinct toward the interior of the body. This flow foliation must result from strain within the pluton during its crystallization. Because the pluton contact and the flow foliation within the pluton margin parallel the foliation in the schist, the pluton emplacement is inferred to have accompanied the deformation that produced this foliation in the country rocks (Table 1). The presence of unfoliated felsic medium-grained to pegmatitic dikes which cut across the schists, the pluton margin, and the interior of the pluton, suggests that crystallization of the igneous body outlasted the deformation.

Tonalite sills occur parallel to the metamorphic foliation in the schists at several localities between the Ecstall pluton contact and the Prince Rupert shear zone (Figure 5a). These sharply bounded concordant sills are tens to a few hundred meters thick. Some of these sills consist of blocks of tonalite/diorite tens of centimeters across, separated by anastomosing thin veins of felsic material. The blocks appear to have been plastically deformed but show no evidence of extensive disruption by flow. The felsic material between the blocks apparently represents the last melt to crystallize. This evidence of internal disruption of the sills before they completely solidified suggests they too were syntectonic. These sills also are locally foliated, particularly along their margins.

The structural and metamorphic features described above define a packet of high pressure kyanite-bearing and locally migmatitic schists and gneisses intruded by the Ecstal1 pluton and simultaneously transported westward and northwestward over slightly lower grade nonmigmatitic schists. The inferred emplacement of the Ecstall pluton during the deformation and ongoing metamorphism of the packet of upper amphibolite grade metamorphic rocks constrains the age of that deformation to
$-98+4 \mathrm{Ma}$ (point a, Figure 3) based on the $\mathrm{U} / \mathrm{Pb}$ zircon date on the Ecstall Pluton [Woodsworth et a1., 1983b]. The field evidence suggests that the uppermost schist and gneiss packet was already at high metamorphic grade at that time. Subsequently, the packet of kyanitestaurolite grade schists that underlies the Ecstall pluton, carrying with it the Ecstall pluton with its envelope of high grade schist and gneiss, was underthrust from the west by the lowermost packet of lower-grade schists. Tonalite sills in the middle packet and plagioclase-phyric sills in the lowermost packet were emplaced and deformed during this interval. As discussed above, the contact between the middle and lower packets lies within the Prince Rupert shear zone. We further infer the biotite through kyanite grade metamorphism in the westernmost lower packet dated at $90+1 \mathrm{Ma}$ [Sutter and Crawford, 1985] was causéd by emplacement under the hot schists of the upper packets (point b, Figure 3). Figure 3 schematically summarizes the pressure, temperature and time relations of these events.

At the eastern end of section $\mathrm{A}^{-} \mathrm{A}^{-}$ (Figure 4, 5a), as elsewhere along the length of Tsimpsean Peninsula within $5 \mathrm{~km}$ of the western shore of Work Channel, structures in the schists and gneisses are steep and trend in a northwesterly direction, paralle1 to the Work Channel. Lineations and fold axes plunge steeply $\left(60^{\circ}-90^{\circ}\right)$ down the dip of the foliation. Along section $\mathrm{A}^{-\mathrm{A}^{-}}$the steeply dipping structures marking the Work Channel lineament zone are overprinted on the recumbent folds associated with Ecstall Pluton emplacement. These steep structures associated with formation and displacement along the Work Channel lineament represent a further deformation of the schists of the western belt. Rotated porphyroblasts with asymmetric tails in augen gneisses along Work Channel suggest vertical movement, with the block on the eastern side of the zone displaced upward. By analogy with the development of shear zones in the central belt described below, and the timing of emplacement of the Quottoon pluton, we date these structures and the movement on the Work Channel lineament zone as being between 65 and $55 \mathrm{Ma}$ (Table 1).

In summary, the western margin of the Coast Plutonic Complex displays crustal thickening accomplished by tectonic transport and stacking of at least three separate rock packets, separated by highly 
deformed zones, with higher-pressure, higher-temperature metamorphic rocks superimposed over lower-grade rocks to the west. Emplacement of an epidote-bearing pluton and tonalite sills accompanied crustal thickening and, we suggest, facilitated transport of the thrust slabs. Cooling of these units to $250^{\circ} \mathrm{C}$ (Figure 3) is recorded by $70 \mathrm{Ma} \mathrm{K} / \mathrm{Ar}$ dates on biotite in the Ecstall pluton and schists on Kaien Island [Hutchison, 1982; Harrison et al., 1979]. A younger ${ }^{40} \mathrm{Ar} /{ }^{39} \mathrm{Ar}$ age of $~ 57 \mathrm{Ma}$ on hornblende [Sutter and Crawford, 1985] occurs close to the Work Channel

lineament.

CENTRAL BELT

The central belt between $54^{\circ}$ and $55^{\circ} \mathrm{N}$ (Figure 2) consists of the Central Gneiss Complex, which is composed of high-grade, mostly migmatitic rocks injected by tonalite sills of Late Cretaceous to Early Tertiary age. For the central belt of the Prince Rupert-Skeena map area we estimate that $40 \%$ of 1 ithologies present before intrusion of tonalite sills and plutons are of sedimentary origin and $60 \%$ are volcanic, mostly felsic but with some andesitic material. These lithologies together presently comprise $50-60 \%$ of the exposed rocks; the rest are intrusive tonalite and leucotonalite sills and plutons.

In the transect area the Central Gneiss Complex can be subdivided into three regions based on lithologic characteristics. The southeastern region extends from the head of the Extew River across the Skeena River; the northern region, from the head of Extew River to Portland Inlet and east of Khutzeymateen Inlet; and the western region extends from Khutzeymateen Inlet to Khtada Lake (Figure 2).

The southeastern region is underlain mainly by grey-weathering biotitehornblende-plagioclase-quartz gneiss and migmatite [Hutchison, 1982]. Unambiguous sedimentary protoliths are rare, but scattered sillimanite and calcsilicatebearing rocks indicate that at least some of the rocks of this region are supracrustal in origin. Hill [1985] describes crinoids in a calcsilicate pod from within this region. The protolith of the grey-weathering gneisses could be andesitic lava flows and/or tonalite sills. The pervasive foliation in these rocks suggests that the grey-weathering gneisses, from which an $85 \mathrm{Ma}$ concordant $\mathrm{U} / \mathrm{Pb}$ date was obtained [Woodsworth et al., 1983b], are older than the relatively undeformed plutons such as the Quottoon, Kasiks, and Ponder plutons. The age of the Quottoon pluton is about $60 \mathrm{Ma}$ based on $\mathrm{a} \mathrm{U} / \mathrm{Pb}$ date [Armstrong and Runkle, 1979].

The northern region of the central belt is underlain predominantly by layered leucogneiss [Hutchison, 1982] which, near Redcap Mountain, is chemically similar to silicic volcanic rocks [Hill, 1984]. This gneiss, which is not migmatitic, gave a nearly concordant $\mathrm{U} / \mathrm{Pb}$ date of $139-\mathrm{Ma}$

[Hill, 1984], significantly older than the 65-85 Ma dates from migmatites in the Central Gneiss Complex. The $139 \mathrm{Ma}$ date gives a minimum age for the protolith of the leucogneiss.

Hill et al. [1985] and Hill [1985] suggest that the protolith of the eastern portion of the central belt represents a metamorphosed equivalent of the Stikine terrane, which forms the eastern belt. They base this suggestion on the chemical similarity of some of the gneisses in the central belt with Lower to Middle Jurassic arc volcanics of the Hazelton Group [van der Heyden, 1982; Hi11, 1984], on the presence of metamorphosed clastic sediments of the Upper Jurassic Bowser Lake Group in the central belt, and on an occurrence in high grade rocks of the central belt of crinoid stems similar to those found in Lower Permian limestones of Stikinia [Hi11, 1985].

The western region is about $50-60 \%$ unambiguous metasedimentary units (abundant sillimanite, calc-silicate-rich layers, $b^{*}$,tite + cummingtonite or hypersti.ene bearing layers); at least $30 \%$ tonalite sills; and the rest, greyweathering gneiss of uncertain origin. Douglas [1986] suggests that metasedimentary rocks that lie south of Khutzeymateen Inlet are arc derived and correlate with the sedimentary part of the Lower Jurassic to Late Cretaceous GravinaNutzotin belt [Berg et al., 1972] in southeast Alaska. Graded beds and channeling with a consistent upward younging direction favor the interpretation that large-scale folding has not overturned the section in this area.

All in all, the protoliths of the central belt appear to be arc-derived sedimentary and volcanic rocks largely of late Paleozoic and Mesozoic age and 


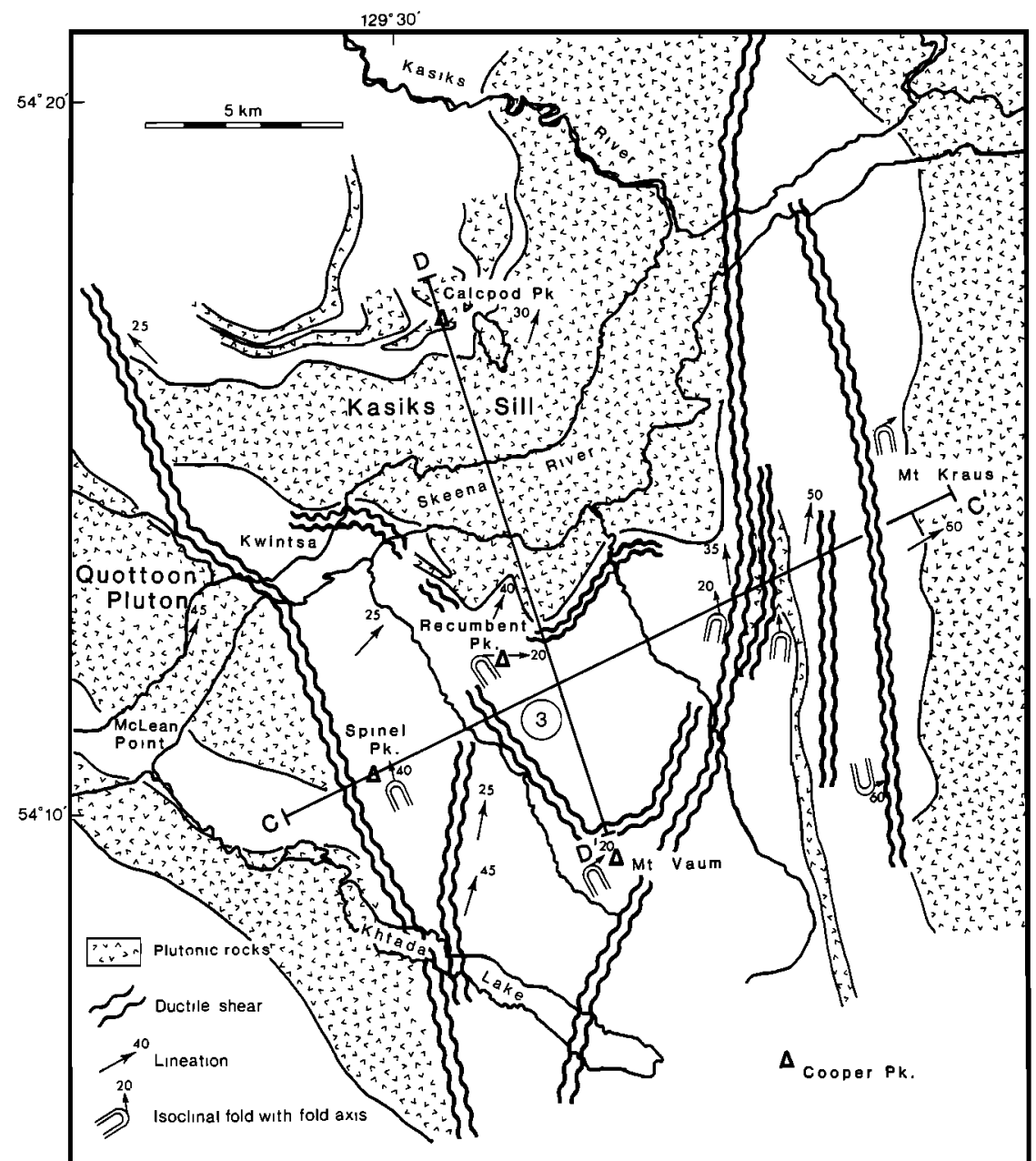

Fig. 6. Map of a portion of the central belt near Khtada Lake (Figure 2), showing the location of cross sections $\mathrm{CC}^{-}$and $\mathrm{DD}^{-}$(Figure 7). Ductile shear zones are marked by wavy lines; the patterned areas are major plutonic bodies.

intruded by a considerable volume of Late Cretaceous to earliest Tertiary tonalite sills, including the Kasiks and Quottoon plutons. These observations support the conclusion reached by Barker and Arth [1984] that the Boca de Quadra segment of the Central Gneiss Complex, in the adjacent Ketchikan Quadrangle to the north, represents the deeply eroded root of an andesitic arc complex.

Detailed studies of the Khtada Lake area (Figures 2 and 6 ) form a basis of interpretation for the structural evolution of the migmatitic parts of the central belt. This area can be divided into relatively coherent domains, each with distinct fold axis and lineation directions, that are bounded by ductile shear zones hundreds of meters wide (Figure 6).
Within domains, foliation, almost everywhere parallel to 1ithologic boundaries, is defined by local concentrations of biotite or sillimanite, by oriented biotite, and by banding in thin leucocratic layers. The latter was probably produced in the presence of a melt phase [Kenah and Hollister, 1983]. The foliation and the compositional layering are folded by large isoclinal folds (Figure 7). Thus some anatexis and therefore substantial heating of the crust had occurred prior to the development of these folds. At the outcrop scale it is common to observe minor folds which tighten toward and are truncated by ductile shear zones that parallel the axial planes of these minor folds. Such shear zones range in width from a few centimeters to tens of meters or more. 

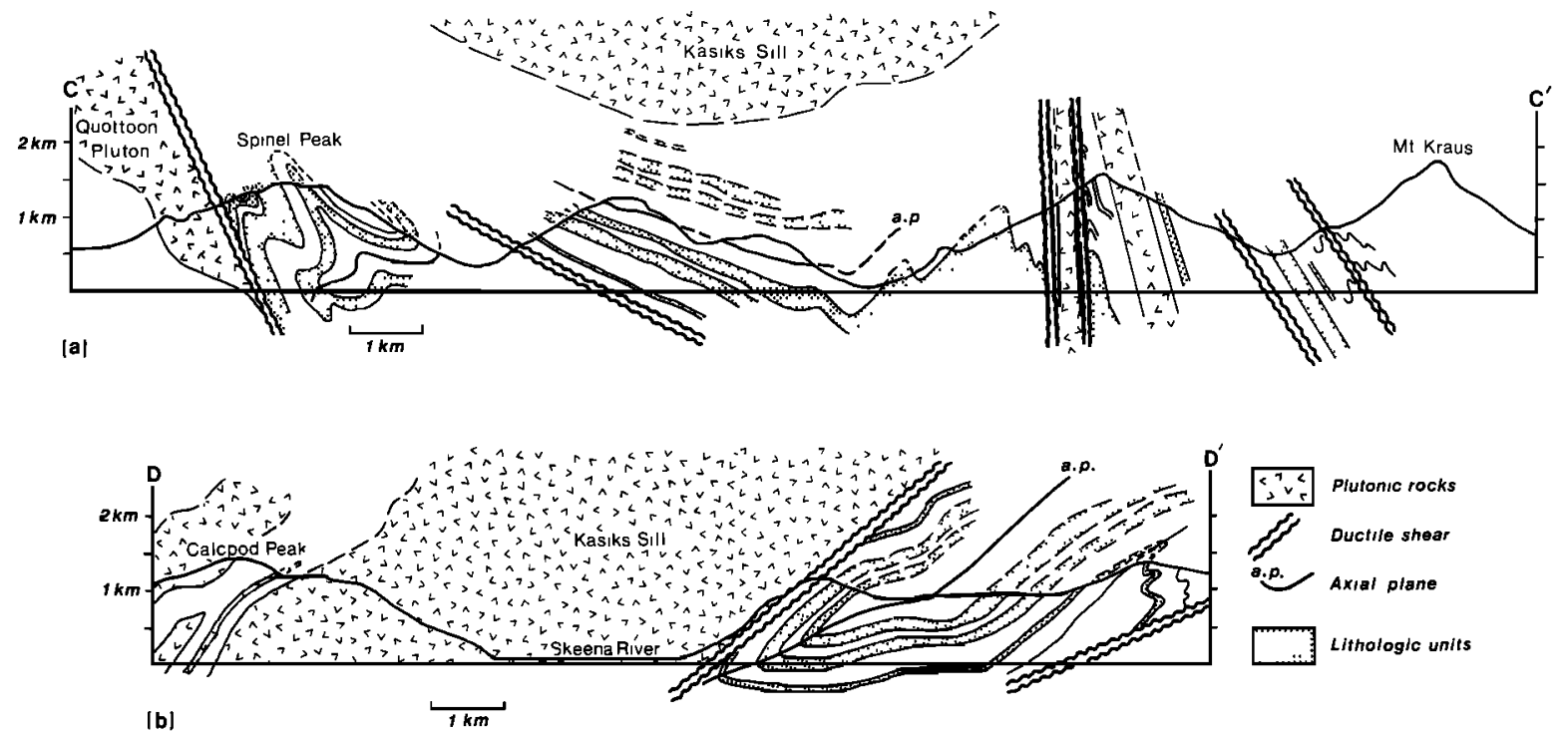

Fig. 7. Cross sections $\mathrm{CC}^{-}$and $\mathrm{DD}^{-}$. Symbols used are as in Figure 6; the dotted pattern marks mappable stratigraphic units; a.p., fold axial plane. No vertical exaggeration.

The foliation in the shear zones consists of gneissic layering with leucocratic segregations up to a few centimeters thick. Within the shear zones are small, isolated isoclinal fold noses, most commonly of calcsilicate lithologies, and isolated slabs or blocks with foliation discordant to that of the shear zone. These appear to be dismembered relics of the surrounding unsheared rocks. We refer to the foliation in these ductile shear zones as a flow foliation.

The degree of development of the flow foliation described above for centimeter to meter scale features increases toward the large ductile shear zones shown on Figure 6 and also toward the lower contact of the Kasiks pluton. Within the shear zones, only the flow foliation is recognized. These large ductile shear zones, hundreds of meters across and mappable, in some cases, for up to $15 \mathrm{~km}$ along strike, are parallel to the axial planes, whether recumbent or upright, of the map scale isoclinal folds.

In the hinge of the large recumbent fold in the Khtada Lake area illustrated in Figure 7 the orientation of minor fold axes and lineations, including aligned sillimanite needles, changes from east plunging to NNE trending as Kasiks pluton is approached from the south. This implies that the recumbent fold formed at sillimanite grade and deformation continued in the stability field of sillimanite during intrusion of the pluton. Primary cumulate textures which locally resulted in hornblende-enriched bands in the Kasiks pluton suggest it was mostly liquid when it intruded. Thus, given its tonalite to diorite composition, this pluton must have been emplaced at about $1000^{\circ} \mathrm{C}$ or higher [Wiley, 1977]. Heat from the pluton locally increased temperatures in the gneiss complex to over $800^{\circ} \mathrm{C}$ [Kenah and Hollister, 1983], promoting further anatexis. We conclude therefore that all recognized structures in the Central Gneiss Complex south of Kasiks pluton formed when the rocks were in the sillimanite field of stability and above $650^{\circ} \mathrm{C}$, the approximate miminum temperature for breakdown of muscovite to orthoclase and sillimanite.

Continuing postintrusion deformation produced the steeply dipping large ductile shear zones, some of which cut the Kasiks and Quottoon plutons (Figure 6), while the high-temperature part of the Central Gneiss Complex and the large tonalite sills remained in a partly molten state. The leucosome of the migmatite has a leucotonalite composition with a melting temperature of about $700^{\circ} \mathrm{C}$ [Johannes, 1978; Kenah and Hollister, 1983]. Thus these shears were developed at temperatures above $700^{\circ} \mathrm{C}$.

Sillimanite first formed probably no 
later than about $85 \mathrm{Ma}$, the oldest concordant $\mathrm{U} / \mathrm{Pb}$ date $\mathrm{from}$ migmatite in the Central Gneiss Complex [Woodsworth et al., 1983b], given that solidus curves are predominantly in the sillimanite stability field. A preliminary $\mathrm{U} / \mathrm{Pb}$ date of $55 \mathrm{Ma}$ on zircons from the Kasiks pluton ( $P$. van der Heyden, personal communication, 1986) suggests that deformation dominated by the large ductile shear zones was in progress and heat was being added to the Central Gneiss Complex some 30 Ma later. Highgrade metamorphic conditions and ductile deformation may have continued in this area through this entire time interval.

An early metamorphism is indicated by local kyanite and staurolite inclusions in garnet [Hollister, 1977; 1982] and other relict metamorphic textures [Selverstone and Hollister, 1980; Hil1, 1984; Douglas, 1986; Sisson, 1985]. These suggest early metamorphism at higher pressures than are inferred for the highest metamorphic temperature assemblages in the central belt. Kyanite and staurolite are absent from the schist matrix everywhere in the central belt, with the exception of one occurrence of staurolite at Redcap Mountain [Hill, 1984]. However, sillimanite pseudomorphs of kyanite and staurolite are widespread. These observations provide the oldest point on the P-T-time path of these rocks ( $c$, path 3, Figure 3). This point is also constrained by the absence of any textures suggesting that garnet occurred in hornblende-rich rocks. Garnet-bearing amphibolites are common in the kyanitebearing rocks of the western belt, suggesting that the western belt schists record higher pressures.

In the Khutzeymateen Inlet area (Figure 2 ), metamorphic temperatures $\left(600^{\circ}-700^{\circ} \mathrm{C}\right)$ barely reached those necessary for partial melting [Douglas, 1986]. Thus complexities of deformation seen at Khtada Lake resulting from strain across me1tcontaining ductile shear zones are absent. The primary sedimentary features preserved in the Khutzeymateen area suggest that the entire section is upright. Therefore, at least on the scale of this area, premetamorphic large-scale recumbent folds are absent. Because of the lack of metamorphic effects directly attributable to the Quottoon pluton (except for some migmatite adjacent to the contact) and because the pluton itself is unmetamorphosed, regional metamorphism probably occurred prior to intrusion of Quottoon pluton. According to Douglas [1986], sillimanite lineation is parallel to early isoclinal intrafolial fold axes that plunge gently north, implying that this deformation was synchronous with metamorphism. Deformation continued and produced upright folds with axes parallel to those of the intrafolial folds. This deformation occurred when the rocks were near their maximum temperature and continued as temperatures dropped.

In summary, the oldest recognizable petrographic feature in the Central Gneiss Complex is a kyanite/ staurolite grade metamorphism ( $c$ on path 3, Figure 3 ). The kyanite/staurolite metamorphism of the western belt is interpreted to have started prior to $98 \mathrm{Ma}$ and lasted until 90 Ma. That of the central belt occurred earlier than $85 \mathrm{Ma}$ (Table 1). No structural fabric has been identified to correlate with growth of the early kyanite and staurolite of the Central Belt. In the Khutzeymateen area, the least deformed part of the central belt, sillimanite pseudomorphs of staurolite in the pelitic parts of graded beds preserve the unmistakable habit of staurolite. We suggest that the kyanite and staurolite crystallized at depth in the tectonically thickened crust generated during the collision of the Alexander terrane with Stikinia. We infer that this stage of the metamorphism was synchronous with the development of the highest-pressure assemblages of the western belt but occurred at somewhat shallower levels.

The oldest recognized structures, large recumbent nappes and isoclinal folds, postdate this kyanite-grade metamorphic episode. These structures formed at sillimanite grade when temperatures were higher and pressures slightly lower ( $d$, path 3, Figure 3). Low-angle ductile shearing and nappe emplacement produced, on a regional scale, a dominantly gently north dipping foliation of the Central Gneiss Complex [Hutchison, 1982]. Woodsworth et a1. [1985] suggest that the orogen formed in a transpressive regime. From our observations we suggest that the recumbent nappes and associated foliation may result from transcurrent motion paralle1 to the orogen. A component of compressive stress perpendicular to the orogen formed the upright open to isoclinal folds following intrusion of the Quottoon and Kasiks plutons but while the plutons still were above their solidus temperature. This compression occurred 
after $55 \mathrm{Ma}$, the probable age of Kasiks pluton. Heat transfer during crystallization of these plutons raised temperatures to $>600^{\circ} \mathrm{C}$ throughout the Central Gneiss Complex and to over $800^{\circ} \mathrm{C}$ south of Kasiks pluton (between $d$ and $e$, Path 3, Figure 3). Continuing deformation produced additional upright folds and the large ductile shears which cut the plutons.

Hollister [1982] argued that the Central Gneiss Complex south of Kasiks pluton was rapidly uplifted from about 60 $\mathrm{Ma}$ to about $48 \mathrm{Ma}$, the date of nearly concordant $\mathrm{K}-\mathrm{Ar}$ ages of hornblende and biotite from this area [Hutchison, 1982] and from southeast Alaska [Smith and Diggles, 1981]. Mineral reaction textures in gneisses of the central belt (locality 3 , Figure 2) show that metamorphic conditions evolved from relatively highpressure and moderate temperature to relatively low-pressure and hightemperature (point e, path 3, Figure 3) prior to cooling to surface conditions. Relatively more uplift for the area south of Kasiks pluton than for the Khutzeymateen Inlet area may account for the regional, gentle northly dip of lithologic layering.

The Work Channel lineament marks the western limit of the area intruded by post 90-Ma plutons, of sillimanite grade metamorphism, and of early Eocene cooling dates. This lineament, therefore, marks a fundamental boundary between the central and western belt rocks. We propose that it is the westernmost of the large ductile shear zones that cut the central belt. Further, we suggest that much of the later stages of uplift of the central belt was concentrated along the Work Channel lineament and other northwest trending ductile shear zones.

\section{EASTERN BELT}

The eastern belt, the western portion of the Intermontane Belt of British Columbia, was never buried to great depth. In the Terrace region, greenschist to zeolite facies sedimentary and volcanic rocks range from Lower Permian to Upper Cretaceous. The main structures are north to east directed thrust faults. Along the Skeena River southwest of Terrace (in the easternmost Central Gneiss Complex) and northeast of Terrace (in low-grade volcanics), stretching lineations generally plunge gently northeast or southwest.
Minor structures indicate northeastward directed transport. The age of this deformation is not known with certainty. Lower Cretaceous (middle Albian) strata are involved, and, in the Whitesail Lake area some $100 \mathrm{~km}$ southeast, Upper Cretaceous rocks may also be involved (Woodsworth and van der Heyden, manuscript in preparation, 1987), suggesting a midCretaceous age for the deformation. There is some stratigraphic support for this suggestion. Albian strata are marine sandstone, siltstone, and shale having an easterly or northeasterly source. The conformably overlying Kasalka volcanics of early Late Cretaceous age are nonmarine. Basal conglomerates of the Rasalka Group contain detritus derived from the west, indicating uplift of the central belt in mid-Cretaceous time.

In most places, Late Cretaceous and early Tertiary postthrusting plutons occupy the contact between the central and eastern belts, and obscure tectonic relations between the two belts. One of these, the Ponder pluton [Sisson, 1985] has superimposed a narrow, low-pressure ( $2.5 \mathrm{kbar}$ ) contact metamorphic aureole on subgreenschist sediments of the eastern belt.

Late Cretaceous and early Tertiary block faulting affects rocks in both the central and eastern belts [Woodsworth, 1979; Woodsworth et a1., 1985]. In the Whitesail Lake area, block faulting affects rocks as young as 01igocene. Block faulting may reflect a change from transpressive tectonics to transtensional and extensional tectonics in the Late Cretaceous (Woodsworth and van der Hayden, in preparation, 1987).

\section{INTERPRETATION}

Our work along this transect allows us to trace the evolution of the Coast Plutonic Complex from mid-Cretaceous (98 Ma) onward with some confidence. Figure 8 summarizes the proposed evolution of the area. 'l'he earlier history is obscured by the intense deformation, metamorphism, and igneous activity in the Late Cretaceous and early Tertiary. Our analysis focuses on the component of tectonic transport that occurred at a high angle to the strike of the orogenic belt, although we recognize that extensive strike-slip motion parallel to the orogen may have occurred during deformation and metamorphism. 

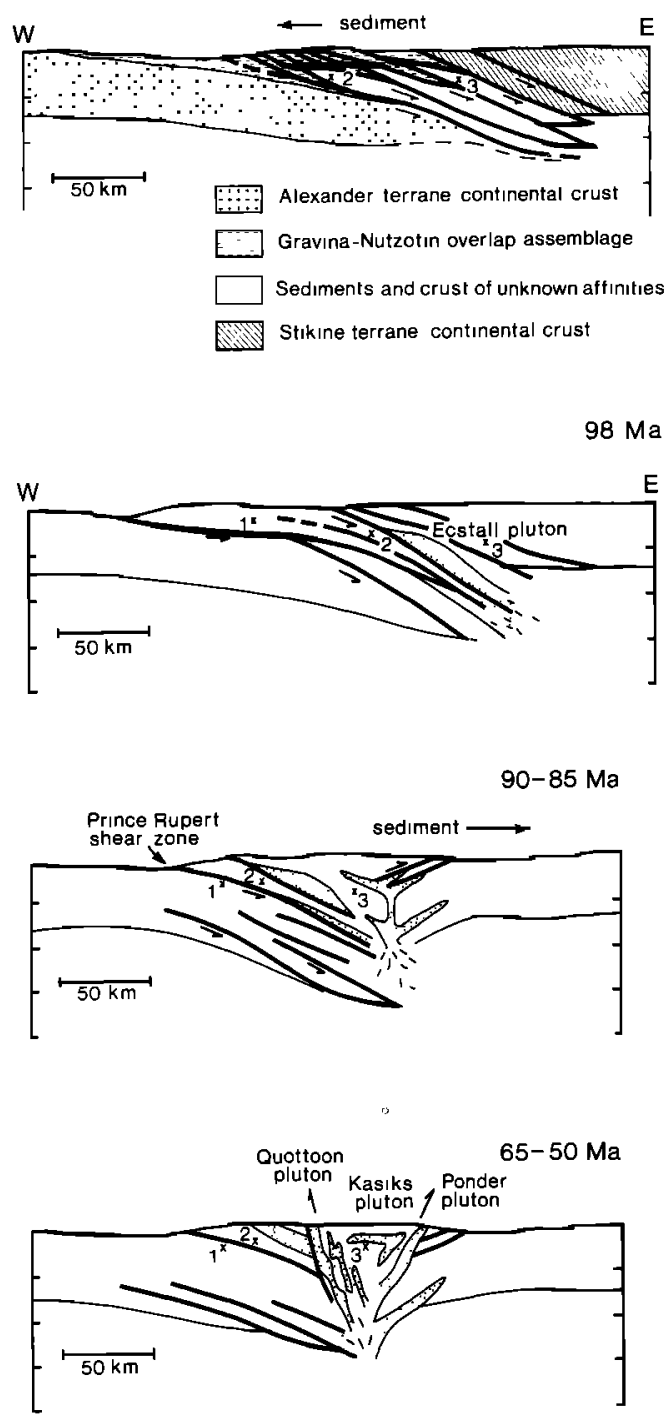

e

$45 \mathrm{Ma}$

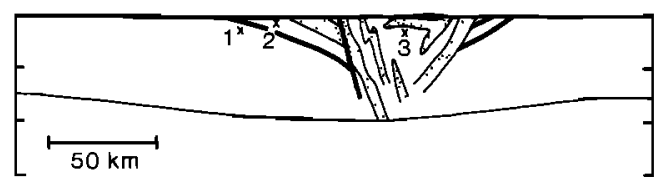

Fig. 8. Sequence of schematic cross sections showing our interpretation of the evolution of the Prince Rupert-Terrace transect, as discussed in the text. The pressure-temperature-time paths for localities 1,2 , and 3 are indicated in Figure 3. The stippled pattern represents plutons, open stipple shows zones of partial melting.
$\mathrm{U} / \mathrm{Pb}$ dates on zircons from southeastern Alaska and along this transect indicate igneous activity as old as $140 \mathrm{Ma}$ [Barker and Arth, 1984; Hill, 1984]. A belt of igneous rocks at least $110 \mathrm{Ma}$ old, including zoned ultramafic plutons, extends from near Ketchikan north past Juneau [Berg et a1., 1972; Brew and Morre11, 1983] and cuts units that can be traced into the western schist belt. Late Jurassic to Early Cretaceous Gravina flysch overlying Paleozoic and Triassic rocks correlative with Alexander terrane is present in the western belt. We have no evidence that connects these Jurassic and Early Cretaceous igneous and sedimentary rocks with a specific tectonic process, but Berg et al. [1972], Godwin [1975], and Barker and Arth [1984] suggest that a volcanic arc and associated sediments had formed on the eastern edge of what is now called Alexander Terrane and elsewhere within our transect by Early Cretaceous time. The position at this time with respect to latitude of the eastern, central and western belts is unknown.

The earliest identified deformation and metamorphism, also inferred to be older than mid-Cretaceous (110-100 Ma), generated the cleavage and intrafolial folds of the first deformation in the lowgrade rocks (locality 1 , Figure 2 ). We also assign this age to kyanite-grade metamorphism in rock units presently exposed in the highest-grade part of the western belt (locality 2, Figure 2) and in the central belt (locality 3, Figure 2). We propose that this metamorphism developed in response to crustal thickening due to collision of two continental crustal slabs, Alexander terrane and Stikinia, and compression of the intervening crust including the Gravina-Nutzotin belt (Figure 8a). In the western belt the earliest structures suggest that crustal thickening was accomplished by underthrusting of western packets of rock under eastern packets (or overthrusting from southeast to northwest). In the central belt the earliest structures have been obliterated, thus there is little direct evidence for the mechanism of crustal thickening in that area. However, the thick, upright section with preserved depositional features in the Khutzeymateen area suggests that the initial crustal thickening was caused by stacking of thick slabs of internally undeformed supra- 
crustal rocks. The total transport distance of overthrust slabs is unknown, but it was constrained by the buoyant forces of subducted continental crust. Continuing deformation was accompanied by the intrusion at $98 \mathrm{Ma}$ of the Ecstall pluton (Figure 8b), tonalite/diorite sills near Prince Rupert, and andesitic dikes in the lower-grade rocks; as well as formation of abundant quartz veins in the lower grade rocks. We propose that these magmas were generated and emplaced as schematically illustrated in Figure $8 \mathrm{~b}$ by melting at the base of the tectonically thickened crust [Hollister and Crawford, 1986]. The evidence for deformation during and after igneous intrusion implies that the melt facilitated and probably enhanced the deformation. The fluid that formed the numerous quartz veins at the top of the lowermost packet may have played a similar role for the lower thrust zone.

At some time between about 90 and 85 $\mathrm{Ma}$, northeaster1y directed thrusting on the eastern side of the complex (Figure $8 c$ ) emplaced high-grade rocks of the central belt structurally above low-grade strata of the eastern belt. This time is marked in the stratigraphic record by a change frotn easterly derived marlne sedimenta to (at least locally) westerly derived conglomerates overla1n by calcalkaline, nonmarine volcanism in the eastern belt. This resurgence of volcanism in the eastern belt indicates an eastern migration and extension of magmetic activity associated with the collisional otogen [Woodsworth, 1979]. Volcanism and high-level plutonism in the eastern belt may be a high-level

expression of the metamorphisin and deformation occurring at a deeper level in the central belt.

If thrusting involved upward transport of deeply buried crustal material and associated magmas and underthusting of surficial rocks, higher-grade rocks should occur structurally above lower-grade rocks, and heating and metamorphism of the lower packets by the hotter higher packets would be expected. In addition, each overthrugt packet would have been cooled by the underthrust colder rocks, locking in the mineral equilibria present at the time of thrusting. Such effects occur in the western schist belt. Inverted metamorphic gradients are also associated with thrusting of hot Central Gneiss Complex rocks eastward over cool rocks of the eastern belt [van der Heyden, 1982].
Tectonic uplift, enhanced by continued underthrusting of material from the west, as well as isostatic uplift and erosion of the tectonically thickened crust, raised the deeper part of the western schist belt to sha1lower levels by the end of the Cretaceous (the cooling age of biotite in the western schists).

The next stage in the development of the Coast Plutonic Complex involved intrusion of voluminous tonalite to diorite sills and plutons from about 75 to $50 \mathrm{Ma}$ and continuing deformation of the rocks of the central belt to form large recumbent nappes. The later stages of this magmatic episode were accompanied by uplift of that belt (Figure 8d). The Kasiks pluton and related sills (Figure 7) imply a minimum of $7 \mathrm{~km}$ of material added to the crust in the central belt at this time. The chemical data reported by Barker and Arth [1984] for similar tonalite along Boca de Quadra in southeastern Alaska suggest that these magmatic rocks originated in the mantle. Cumulate plagioclase and amphibole in these igneous bodies imply a hot $\left(>1000^{\circ} \mathrm{C}\right)$ magma during intrusion which also implies a mantle or very deep crustal origin for the magma. Settling of early crystallizing orthopyroxene and hornblende in the tonalite sills and plutons could have produced the small bodies of orthopyroxenite and hornblendite found within the Work Channe1 lineament zone and scattered through the central belt, although a mantle origin for these ultramafic bodies cannot be ruled out. In the eastern belt and eastern part of the central belt, the period from 75 to $50 \mathrm{Ma}$ was marked by high-level plutonism, calc-alkaline volcanism, and block

faulting.

The major uplift surge, which terminated at about $48 \mathrm{Ma}$ [Hollister, 1982], is shown in Flgures $8 \mathrm{~d}$ and $8 \mathrm{e}$. We infer that several major steep to vertical ductile shear zones formed during this interva1. The westernmost of these follows Work Channel lineament. The Quottoon pluton was emplaced prior to or at the beginning of uplift. Vertically aligned magmatic hornblende crystals in the pluton that parallel steep lineations in the shear zone along the lineament suggest that the pluton was syntectonic and may have facilitated uplift of the central belt block. This uplift was also probably facilitated by the formation of significant amounts of anatectic melt. Such melt and tonalite magma accumulated 
along shear zones within the central belt (Figure 6), resulting in enhanced ductility of this part of the crust. Syntectonic and posttectonic granodiorite and granite, including parts of Ponder pluton, record extensive early Tertiary igneous activity along much of the boundary between high-grade gneisses of the central belt and low-grade strata of the eastern belt. The latter show contact metamorphism at 2-3 kbar next to Ponder pluton [Sisson, 1985]. Brittle, extensional faulting probably occurred in all three belts during uplift, and continued into the oligocene in the eastern belt.

Uplift rates in the western belt averaged about $1 \mathrm{~mm} / \mathrm{yr}$ between 98 and 70 Ma. Uplift of the central zone was at a rate of about $1 \mathrm{~mm} / \mathrm{yr}$ between 60 and $48 \mathrm{Ma}$ (Figure $8 \mathrm{e}$ ). From about $45 \mathrm{Ma}$ to the Miocene the present erosion surface was at a depth of about $5 \mathrm{~km}$ (Figure $8 \mathrm{e}$ ). PostMiocene uplift [Parrish, 1983] and Pleistocene glaciation brought the rocks to the surface.

Our final conclusion is that weakening of the crust in the presence of melt and of compressive stress leads to rapid deformation and substantial uplift due to a drop in strength across zones occupied by melt [Hollister and Crawford, 1986]. This process may be a general characteristic of the collision of fragments of continental crust.

Acknowledgments. The research reported here was supported by NSF Grants EAR 78-00349, EAR 81-00398, and EAR 840174 to M.L. Crawford and EAR 83-17341 and 83-19249 to L.S. Hollister. This paper represents the collaborative efforts of a large group of people. We could not have reached these interpretations without the data provided by our many students, including our field assistants and those who wrote senior theses: J. Hampson, H. Kelsey, J. Selverstone, G. Grissom, D.J. Wood, K. Peters, M. Sherwood, A. Cochran, E. $0^{\prime}$ Leary, S. Eldredge; and our graduate students: C. Kenah, A. Lappin, B. Douglas, D. Kraus, M.L. Hill, V.B. Sisson, H. Stowe11, J. Snyder, S. Krage, and J. Petrie. The field work prospered due to the strong support of colleagues at the Geological Survey of Canada in Vancouver as well as the logistical expertise and friendship of D, Newman and E. Wampler. P. van der Heyden (University of British Columbia) contributed unpublished U/Pb dates, as well as ideas and field data.
Colleagues who participated in the 1983 GAC field trip in the area, specially $P$. Coney, encouraged us to synthesize our thoughts. E. Zen, E. McLe1lan, F. Barker, J.0. Wheeler, E. Ghent, and an anonymous reviewer provided valuable feedback and constructive suggestions on the manuscript. Geological Survey of Canada Contribution 14686.

\section{REFERENCES}

Armstrong, R. L, , and D. Runkle, Rb-Sr geochronometry of the Ecstall, Kitkiata, and Quottoon plutons and their country rocks, Prince Rupert region, Coast Plutonic Complex, British Columbia, Can. J. Earth Sc1. , 16, 387-399, 1979.

Barker, F., and J. G. Arth, Preliminary results, Central Gneiss Complex of the Coast Range Batholith, southeast Alaska: The root of a high-K andesitic arc?, Phys. Earth Planet. Inter., 35, 191-198, 1984 .

Berg, H, C., D. L. Jones, and D. H. Richter, Gravina-Nutzotin Belt - Tectonic significance of an upper Mesozo1c sedimentary and volcanic sequence in southern and southeastern Alaska, U.S. Geol. Surv. Prof. Pap., 800-D, D1-D24, 1972 .

Berg, H. C., R. L. Elliott, J. G. Smith, and R. D. Koch, Geologic map of the Ketchikan and Prince Rupert quadrangles, Alaska, U.S. Geol. Surv, Open File Rep. 78-73-A, 1978 ,

Brew, D, A., and A. B. Ford, Megalineament in southeastern Alaska marks southwest edge of Coast Range batholithic complex, Can. J. Earth Sc1., 15, 1763-1772, 1978.

Brew, D. A., and R. P. Morre11, Intrusive rocks and plutonic belts of southeastern Alaska, U.S.A., Mem. Geol. Soc. Am., 159, 171-193, 1983.

Crawford, M. L., and L. S, Hollister, Contrast of metamorphic and structural histories across the Work Channel lineament, Coast Plutonic Complex, British Columbia, J. Geophys. Res., 87 , $3849-3860,1982$.

Crawford, M. L., and L. E. Mark, Evidence from metamorphic rocks for overthrusting, Pennsylvania Piedmont, U.S.A., Can. Minera1., 20, 333-347, 1982.

Crawford, M. L., D. W. Kraus, and L. S. Hollister, Petrologic and fluid inclusion study of calc-silicate rocks, Prince Rupert, British Columbia, Am. J. Sci., 279, 1135-1159, 1979.

Dewey, J. F., and K. Burke, Tibetan, 
Variscan, and Precambrian reactivation products of continental collision, J. Geol., 81, 683-692, 1973.

Douglas, B. J., Deformational history of an outlier of metasedimentary rocks, Coast Plutonic Complex, British Columbia, Canada, Can. J. Earth Sci., 23, 813-826, 1986.

Ferry, J. M., and F. S. Spear, Experimental calibration of the partitioning of $\mathrm{Fe}$ and $\mathrm{Mg}$ between biotite and garnet, Contrib. Mineral. Petrol., 66, 113-117, 1978.

Ghent, E., Plagioclase-garnet-Al ${ }_{2} \mathrm{SiO}_{5}-$ quartz: A potential geothermometer $\underline{5}$ geobarometer, Am. Minera1., 61, 710-714, 1976.

Godwin, C. I., Imbricate subduction zones and their relationships with Upper Cretaceous to Tertiary porphyry deposits in the Canadian Cordillera, Can. J. Earth Sci., 12, 1362-1378, 1975.

Harrison, T. M., R. L. Armstrong, C. W. Naeser, and J. E. Harahal, Geochronology and thermal history of the Coast Plutonic Complex, near Prince Rupert, British Columbia, Can. J. Earth Sci., 16, 400-410, $1 \overline{979}$.

Hill, M. L., Geology of the Redcap Mountain area, Coast Plutonic Complex, British Columbia, Ph.D. thesis, 216 pp., Princeton Univ., Princeton, N. J., 1984.

Hill, M. L., Remarkable fossil locality: Crinoid stems from migmatite of the Coast Plutonic Complex, British Columbia, Geology, 13, 825-826, 1985.

Hi 11, M. L., G. J. Woodsworth, and P. van der Heyden, The Coast Plutonic Complex near Terrace, G.C.: A metamorphosed western extension of Stikinia, Geol. Soc. Am. Abstr. Programs, 17, 362, $1 \overline{985 .}$

Hollister, L. S., The reaction forming cordierite from garnet, the Khtada Lake metamorphic complex, British Columbia, Can. Mineral., 15, 217-229, 1977.

Hollister, L. S., Metamorphic evidence for rapid ( $2 \mathrm{~mm} / \mathrm{yr}$ ) uplift of a portion of the Central Gneiss Complex, Coast Mountains, British Columbia, Can. Mineral., 20, 319-332, 1982.

Hollister, L. S., and M. L. Crawford, Meltenhanced deformation: A major tectonic process, Geology, 14, 558-561, 1986.

Hutchison, W. W., Geology of the Prince Rupert-Skeena map area, British Columbia, Mem. Geo1. Surv. Can., 394, 1-116, 1982.

Johannes, W., Melting of plagioclase in the systems $\mathrm{Ab}-\mathrm{An}-\mathrm{H}_{2} \mathrm{O}$ and $\mathrm{Qz}-\mathrm{Ab}-\mathrm{An}-\mathrm{H}_{2} \mathrm{O}$ at $\mathrm{P}_{\mathrm{H} 2 \mathrm{O}}=5 \mathrm{kbar}$, an equilibrium problem, Contrib. Mineral. Petrol., 66, 295-303, 1978.
Kenah, C., and L. S. Hollister, Anatexis in the Central Gneiss Complex, British Columbia, in Migmatites, Melting and Metamorphism, edited by M. P. Atherton and C. D. Gribble, pp. 142-162, Shiva Pub1. Co., Nantwich, England, 1983.

Monger, J. W. H., R. A. Price, and D. J. Templeman-Kluit, Tectonic accretion and the origin of the two major metamorphic and plutonic welts in the Canadian Cordillera, Geology, 10,70-75, 1982.

Oxburgh, E. R., and D. L. Turcotte, Thermal gradients and regional metamorphism in overthrust terrains with special reference to the Eastern Alps, Schweiz. Mineral. Petrogr. Mitt., 54, 641-662, 1974.

Parrish, R. R., Cenozoic thermal evolution and tectonics of the Coast Mountains of British Columbia 1, Fission track dating, apparent uplift rates, and patterns of uplift, Tectonics, 2, 601-631, 1983.

Selverstone, J., and $\overline{\mathrm{L}}$. S. Hollister, Cordierite-bearing granulites from the Coast Ranges, British Columbia: P-T conditions of metamorphism, Can. Minera1., 18, 119-129, 1980.

Sisson, V. B., Contact metamorphism and fluid evolution associated with the intrusion of the Ponder Pluton, Coast Plutonic Complex, British Columbia, Canada, Ph.D. thesis, 345 Pp., Princeton Univ., Princeton, N. J., 1985.

Smith, J. G., and M. F. Diggles, Potassium-argon determinations in the Ketchikan and Prince Rupert quadrangles, southeastern Alaska, U.S. Geol. Surv.

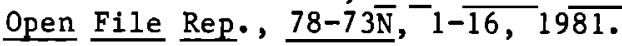

Sutter, J. F., and M. L. Crawford, Timing of metamorphism and uplift in the vicinity of Prince Rupert, British Columbia and Ketchikan, Alaska, Geol. Soc. Am. Abstr. Programs, 17, 41 1985. van der Heyden, P., Tectonic and stratigraphic relationships between the Coast Plutonic Complex and Intermontane Belt, west central Whitesall map area, British Columbia, M.A. thesis, 172 pp., Univ. of British Columbia, Vancouver, B.C., 1982.

van der Heyden, P., Coast Plutonic Complex-Intermontane belt transition in Whitesail Lake map area, B.C.: Margin of a transpressive-transtenstional orogen?, Geol. Soc. Am. Abstr. Programs, 17, 415, 1985.

Wells, P. R. A., Thermal models for the magmatic accretion and subsequent metamorphism of continental crust, Earth Planet. Sci. Lett., 46, 253-265, 1980 . 
Wiley, P. J., Crustal anatexis: An experimental review, Tectonophysics, 43, 41-72, 1977.

Woodsworth, G. J., Geology of the Whitesail Lake map-area, British Columbia, Geol. Surv. Can. Current Res., Part A, $\underline{\text { Paper }}$ $\overline{79-1 A}, \overline{71}-7 \overline{5,1979}$.

Woodsworth, G. J., and M. J. Orchard, Upper Paleozoic to lower Mesozoic strata and their conodonts, western Coast Plutonic Complex, British Columbia, Can. J. Earth Sci., 22, 1329-1344, 1985.

Woodsworth, G. J., M. L. Crawford, and L. S. Hollister, Metamorphism and structure of the Coast Plutonic Complex and adjacent belts, Prince Rupert and Terrace areas, British Columbia, Geol. Assoc. Can. Field Trip Guidebook, $14, \overline{66 \mathrm{pp}}$., 1983a.

Woodsworth, G. J., W. D. Loveridge, R. R. Parrish, and R. W. Sullivan, Uranium-lead dates from the Central Gneiss Complex and Ecstall pluton, Prince Rupert map area,
British Columbia, Can. J. Earth Sci., 20, 1475-1483, 1983b.

Woodsworth, G. J., P. van der Heyden, and M. L. Hill, Regional tectonic styles in the Coast Mountains between 52 and $55^{\circ} \mathrm{N}$, B.C., Geol. Soc. Am. Abstr. Programs, 17, $418,19 \overline{985}$

Zen, E., and J. M. Hammarstrom, Magmatic epidote and its petrologic significance, Geology, 12, 515-518, 1984.

M. L. Crawford, Department of Geology, Bryn Mawr College, Bryn Mawr, PA 19010. L. S. Hollister, Department of Geological and Geophysical Sciences, Princeton Univeristy, Princeton, NJ 08544. G. J. Woodsworth, Geological Survey of Canada, 100 West Pender Street, Vancouver, BC Canada V6B 1R8.

(Received June 11, 1985;

revised January 1, 1987 ;

accepted February 13, 1987.) 